\title{
Importance and indications of tilt-table testing in patients with unexplained syncope
}

\author{
Marko Mornar Jelavić ${ }^{1 *}$, \\ Zdravko Babić², \\ Hrvoje Hećimović ${ }^{2}$, \\ Vesna Erceg², \\ Hrvoje Pintarić ${ }^{2}$
}

${ }^{1}$ Health Centre Zagreb - East, Zagreb, Croatia

University Hospital Centre "Sestre milosrdnice", Zagreb, Croatia

\begin{abstract}
KEYWORDS: cardioinhibitory syncope, seizures, tilt-up table-test, permanent pacemaker, epilepsy. CITATION: Cardiol Croat. 2015;10(9-10):241. | DOI: http://dx.doi.org/10.15836/ccar.2015.241

*ADDRESS FOR CORRESPONDENCE: Dom Zdravlja Zagreb - Istok, Ninska 10, HR-10000 Zagreb, Croatia. Phone: +385-91-7826-135 / E-mail: mjelavic@yahoo.com
\end{abstract}

ORCID: Marko Mornar Jelavić, http://orcid.org/0000-0002-9135-1820 • Zdravko Babić, http://orcid.org/0000-0002-7060-8375 Hrvoje Hećimović, http://orcid.org/0000-0002-6567-8571 • Vesna Erceg, http://orcid.org/0000-0001-9122-6221 Hrvoje Pintarić, http://orcid.org/0000-0002-7741-4194

||||||||||||||||||||||||||||||||||||||||||||||||||||||||||||||||||||||||||||||||||||||||||||||||||||||||||||||||||||||||||||||||||||

AIM: To investigate the importance and indications of head-up tilt-testing (HUTT) in patients with unexplained syncope.

PATIENTS AND METHODS: We retrospectively analyzed 235 patients who underwent HUTT, between February 2012 and September 2014 at the Department of Cardiology, University Hospital Centre "Sestre milosrdnice" Zagreb. They were divided in three groups according to the HUTT indications as follows: Group A (convulsive syncope, n=30), Group B (suspected vasovagal syncope, n=180) and Group C (paroxysmal vertigo, $\mathrm{n}=25$ ). The groups were analyzed by their baseline parameters (age, gender, referral specialists (cardiologists, neurologists, others)), HUTT results (positive/negative) and specific responses (cardioinhibitory, vasodepressor, or mixed).

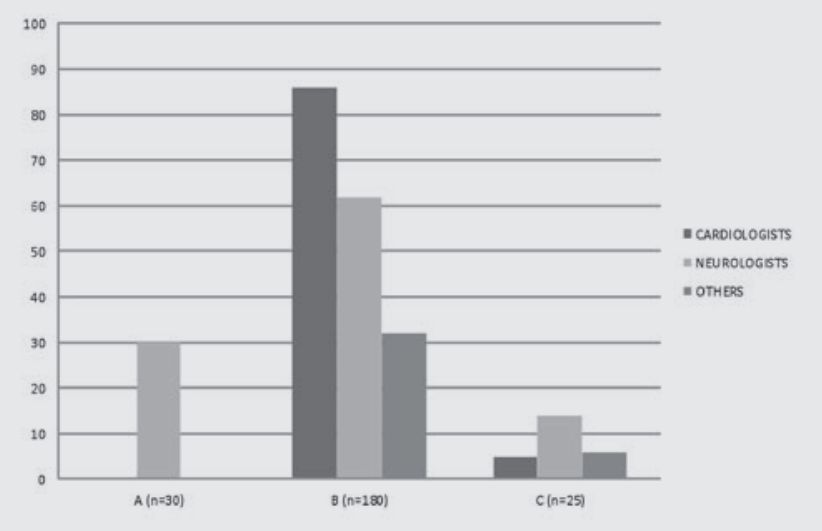

FIGURE 1. Comparison of specialists' referral to tilt-table testing in patients with convulsive syncope (A), suspected vasovagal syncope (B) and paroxysmal vertigo (C).

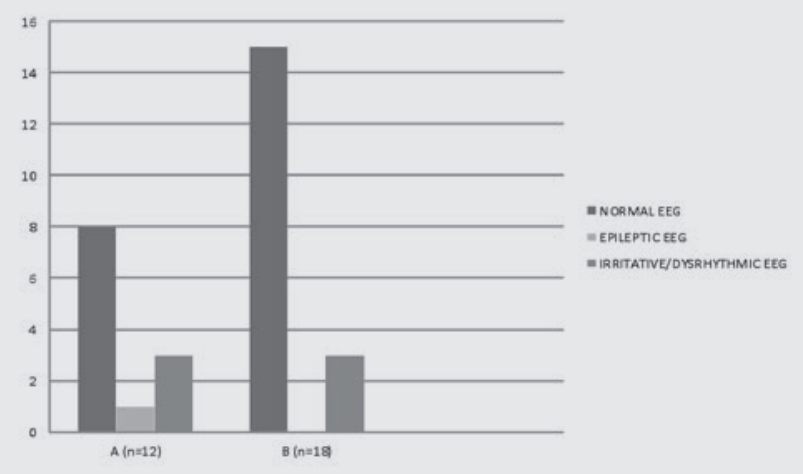

FIGURE 2. Electroencephalographic findings in patients with convulsive syncope: 12 patients with antiepileptic drugs (A) and in 18 patients with no medication (B).
RECEIVED:

August 18, 2015

ACCEPTED:

September 17, 2015

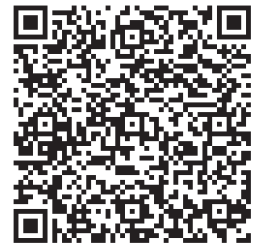

RESULTS: Groups A and B were referred most frequently to the HUTT by neurologists and cardiologists ( $p<0.05$ ) (Figure 1). It was positive in 34 (14.5\%) patients (5 in Group A and 29 in Group B), i.e. 13 (38.2\%) patients had cardioinhibitory, 11 (32.4\%) mixed and 10 (29.4\%) vasodepressor response (Figure 2). In cardioinhibitory subgroup, there were 3 patients (23.1\%, 2 males/1 female, mean age 28.5 years) with normal EEG and on antiepileptic drugs. During HUTT, they had typical convulsions with cardioinhibition and bradycardia (heart

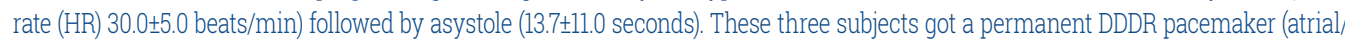
ventricular stimulation, HR control) and anticonvulsive therapy was slowly withdrawn. They had no syncope recurrences during 24 months of follow-up.

CONCLUSION: HUTT has an important role in evaluation of the patients with unexplained syncope. It is indicated in differential diagnosis of vasovagal syncope, especially in patients with syncope accompanied with convulsive elements. ${ }^{1.3}$ Finally, pacemaker implantation is effective in preventing syncope relapses in patients with cardioinhibitory convulsive syncope.

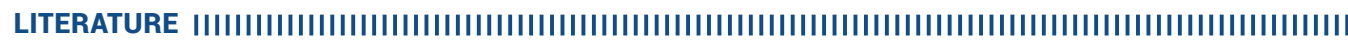

1. Zaidi A, Clough P, Cooper P, Scheepers B, Fitzpatrick AP. Misdiagnosis of epilepsy: many seizure-like attacks have a cardiovascular cause. J Am Coll Cardiol. 2000;36:181-4. DOI: http://dx.doi.org/10.1016/50735-1097(00)00700-2

2. Task Force for the Diagnosis and Management of Syncope; European Society of Cardiology (ESC); European Heart Rhythm Association (EHRA): Heart Failure Association (HFA): Heart Rhythm Society (HRS), Moya A, Sutton R, Ammirati F, Blanc JJ, Brignole M, Dahm JB, et al. Guidelines for the diagnosis and management of syncope (version 2009). Task Force for the Diagnosis and Management of Syncope. Eur Heart J. 2009; 30(21): 2631-71. DOI: http://dx.doi.org/10.1093/eurheartj/ehp298

3. Brignole M, Auricchio A, Baron-Esquivias G, Bordachar P, Boriani G, Breithardt OA, et al. 2013 ESC Guidelines on cardiac pacing and cardiac resynchronization therapy: the Task Force on cardiac pacing and resynchronization therapy of the European Society of Cardiology (ESC). Developed in collaboration with the European Heart Rhythm Association (EHRA). Eur Heart J. 2013;34(29):2281-329. DOI: http://dx.doi.org/10.1093/eurheartj/eht150. 